Article

\title{
Four New Insecticidal Xanthene Derivatives from the Mangrove-Derived Fungus Penicillium sp. JY246
}

\author{
Meng Bai ${ }^{1,2, \dagger}$, Cai-Juan Zheng ${ }^{1,2,+}{ }^{,}$Xu-Hua Nong ${ }^{1,2}$, Xue-Ming Zhou ${ }^{1,2}$, You-Ping Luo ${ }^{1,2}$ \\ and Guang-Ying Chen ${ }^{1,2, *}$ \\ 1 Key Laboratory of Tropical Medicinal Resource Chemistry of Ministry of Education, Hainan Normal \\ University, Haikou, Hainan 571127, China; xxbai2014@163.com (M.B.); caijuan2002@163.com (C.-J.Z.); \\ nongxuhua4883@163.com (X.-H.N.); xueming2009211@126.com (X.-M.Z.); dengpengfei@gmail.com (Y.-P.L.) \\ 2 Key Laboratory of Tropical Medicinal Plant Chemistry of Hainan Province, College of Chemistry and \\ Chemical Engineering, Hainan Normal University, Haikou, Hainan 571127, China \\ * Correspondence: cgy@hainnu.edu.cn; Tel.: +86-898-6588-9422; Fax: +86-898-6588-9422 \\ + These authors contributed equally to this work.
}

Received: 28 September 2019; Accepted: 13 November 2019; Published: 20 November 2019

check for updates

\begin{abstract}
Four new xanthene derivatives, penicixanthenes A-D (1-4), and one known compound 5 were isolated from a marine mangrove endophytic fungus Penicillium sp. JY246 that was obtained from the stem of Ceriops tagal. Their structures were determined by detailed NMR, MS spectroscopic data, modified Mosher's method, and calculated electronic circular dichroism data. All of the isolated compounds were examined for insecticidal activity. Compounds $\mathbf{2}$ and $\mathbf{3}$ showed growth inhibition activity against newly hatched larvae of Helicoverpa armigera Hubner with the $\mathrm{IC}_{50}$ values 100 and 200 $\mu \mathrm{g} / \mathrm{mL}$, respectively, and compounds 1,3 , and 4 showed insecticidal activity against newly hatched larvae of Culex quinquefasciatus with $\mathrm{LC}_{50}$ values of $38.5( \pm 1.16), 11.6( \pm 0.58)$, and $20.5( \pm 1) \mu \mathrm{g} / \mathrm{mL}$, respectively. The four xanthene derivatives have the potential to be developed as new biopesticides.
\end{abstract}

Keywords: Penicillium sp.; Ceriops tagal; xanthene; insecticidal activity

\section{Introduction}

Fungal secondary metabolites have always been considered an important source for drug discovery due to their diverse chemical structures and bioactivities [1]. Among them, Penicillium are recognized as important producers of structurally unusual natural products, especially of terpenes with pharmaceutical potential as illustrated with chrysogenester, an anti-inflammatory meroterpenoid-type derivative [2], shearilicine, a cytotoxic indole-diterpenoid possessing a rare carbazole unit [3,4], and the penerpenes, unusual indole-terpenoids which have shown potent protein tyrosine phosphatase inhibitory activity [5]. Insecticidal agents were also reported for penicianstinoid A, an austinoid-like meroterpenoid [6], as well as plant regulators for the dongtingnoids, diterpenoid glycosides which revealed promising seed-germination-promoting activities [7]. Accordingly, strains of Penicillium have gained considerable attention due to their ability to produce unusual secondary metabolites and have proved to be a prolific source of bioactive compounds.

In our search for new bioactive compounds from fungal sources [6,8,9], the fungus Penicillium sp. JY246 was isolated from the mangrove's stem Ceriops tagal, collected from the South China Sea. The EtOAc extract of the fermentation broth showed significant activity against newly hatched larvae of Helicoverpa armigera Hubner. Chemical investigation of the fungus fermentation's organic extract resulted in the isolation of four new xanthene derivatives (1-4), along with one known compound 5 (Figure 1). Herein, the isolation, structure elucidation, and insecticidal activity of these compounds are described. 
<smiles>C[C@H]1C[C@@H]2c3c(O)cccc3Oc3cccc(c32)O1</smiles>

1<smiles>CC(O)CC1c2ccc(O)c(C(=O)CC[18F])c2Oc2cccc(O)c21</smiles>

$29 R$<smiles>CCCC(=O)c1c(O)ccc([C@H]2CCC(=O)c3cccc(OC)c32)c1O</smiles>

4<smiles>CCCC(=O)c1c(O)cccc1O</smiles>

5

Figure 1. Chemical structures of compounds 1-5.

\section{Results and Discussion}

\subsection{Structure Elucidation}

Compound 1 was obtained as a white amorphous powder, and its molecular formula was determined to be $\mathrm{C}_{16} \mathrm{H}_{14} \mathrm{O}_{3}$ based on HRESIMS (Figure S8), accounting for 10 degrees of unsaturation. Analysis of the ${ }^{1} \mathrm{H}$ NMR spectrum (Table 1, Figure S1) displayed six olefinic proton signals at $\delta_{\mathrm{H}}$ $7.05(\mathrm{dd}, J=8.4,8.4 \mathrm{~Hz}, \mathrm{H}-6), 7.04(\mathrm{dd}, J=8.0,8.0 \mathrm{~Hz}, \mathrm{H}-3), 6.58(\mathrm{dd}, J=8.0,0.8 \mathrm{~Hz}, \mathrm{H}-4), 6.55(\mathrm{dd}$, $J=8.0,0.8 \mathrm{~Hz}, \mathrm{H}-2), 6.52(\mathrm{dd}, J=8.4,1.2 \mathrm{~Hz}, \mathrm{H}-5)$, and $6.50(\mathrm{dd}, J=8.4,1.2 \mathrm{~Hz}, \mathrm{H}-7)$; two methine signals at $\delta_{\mathrm{H}} 4.64(\mathrm{~m}, \mathrm{H}-11)$ and $3.99(\mathrm{dd}, J=12.4,4.0 \mathrm{~Hz}, \mathrm{H}-9)$; one methylene group at $\delta_{\mathrm{H}} 3.17$ (ddd, $J=13.2,4.0,1.6 \mathrm{~Hz}, \mathrm{H}-10 \mathrm{~b})$ and $1.79(\mathrm{dt}, J=12.4,6.4 \mathrm{~Hz}, \mathrm{H}-10 \mathrm{a})$; and one methyl signal at $\delta_{\mathrm{H}} 1.39(\mathrm{~d}$, $J=6.4 \mathrm{~Hz}, \mathrm{H}-12)$. Interpretation of the ${ }^{13} \mathrm{C}$ NMR and DEPT spectra (Table 2, Figures S2 and S3) revealed 16 carbon signals, attributable to twelve $\mathrm{sp}^{2}$-hybridized carbons $\left(\delta_{C} 156.9,154.3,152.3,150.1,127.9\right.$, $127.8,110.4,110.2,109.3,109.1,107.0$ and 106.5) indicating the presence of two benzene rings, two $\mathrm{sp}^{3}$ methine groups $\left(\delta_{C} 71.7\right.$ and 22.3), one $\mathrm{sp}^{3}$ methylene group $\left(\delta_{C} 33.0\right)$, and one methyl group $\left(\delta_{C} 20.7\right)$. The detailed structure of $\mathbf{1}$ was identified by interpretation of the COSY (Figure S6) and HMBC spectra (Figure 2 and Figure S5). The key HMBC correlations from H-9 to C-4a/C-4b, and further- $\mathrm{H}-10 \mathrm{~b}$ to C-8a/C-8b, H-11 to C-8/C-9, and $\mathrm{H}_{3}-12$ to $\mathrm{C}-10 / \mathrm{C}-11$-indicate that C-9 linked the two benzene rings at C-8a/C-8b, and the HMBC correlations from H-3 to C-4a and H-6 to C-4b indicated the presence of one oxygen bridge between $\mathrm{C}-4 \mathrm{a}$ and $\mathrm{C}-4 \mathrm{~b}$. So, the two benzene rings were connected through $\mathrm{C}-9$ and oxygen-bridge to build up the skeleton of 9-methylene-9H-xanthene [10]. Furthermore, $\mathrm{C}-11$ linked to C-8 through the oxygen bridge was deduced by chemical shift at C-8 $\left(\delta_{C} 154.3\right)$ and $C-11\left(\delta_{C} 71.7\right)$. Hereto, the planar structure of $\mathbf{1}$ was elucidated (Figure 1).

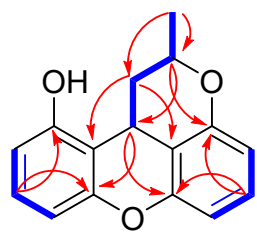

1

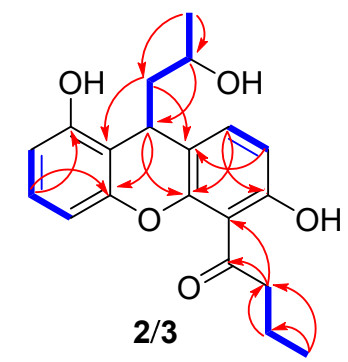

$2 / 3$

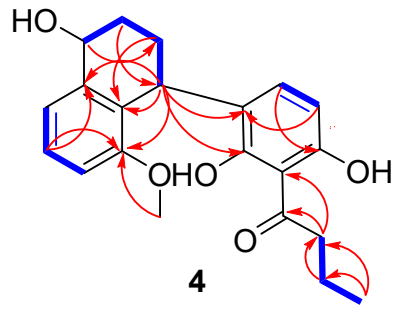

4

${ }^{1} \mathrm{H}-{ }^{1} \mathrm{H}$ COSY

HMBC

Figure 2. ${ }^{1} \mathrm{H}_{-}{ }^{1} \mathrm{H}$ COSY correlations and key HMBC correlations for compounds 1-4.

The relative configuration of 1 was revealed by the NOESY experiment (Figure 3 and Figure S7). The NOESY correlations of $\mathrm{H}-9$ to $\mathrm{H}_{3}-12$ indicated that $\mathrm{H}-9$ and $\mathrm{H}_{3}-12$ were on the contrary side of the $\mathrm{H}-11$. The absolute configuration of $\mathbf{1}$ was determined by comparing experimental and calculated electronic circular dichroism (ECD) spectra for the truncated model $(9 R, 11 S)-\mathbf{1}$ and the truncated 
model $(9 S, 11 R)-1$ using time-dependent density-functional theory (TDDFT). The DFT reoptimization of the initial Merck molecular force field (MMFF) minima was performed at the B3LYP/6 $-31+g(d$, p) level with a conductor-like polarizable continuum model (CPCM) solvent model for MeOH [11]. The theoretical spectrum of $\mathbf{1}$ showed the same Cotton effect with the experimental plot recorded in $\mathrm{MeOH}$ (Figure 4), which supported that the absolute configuration was 9S, 11R. Thus, the completed structure of $\mathbf{1}$ was elucidated as depicted in Figure 1, and was named penicixanthene A.
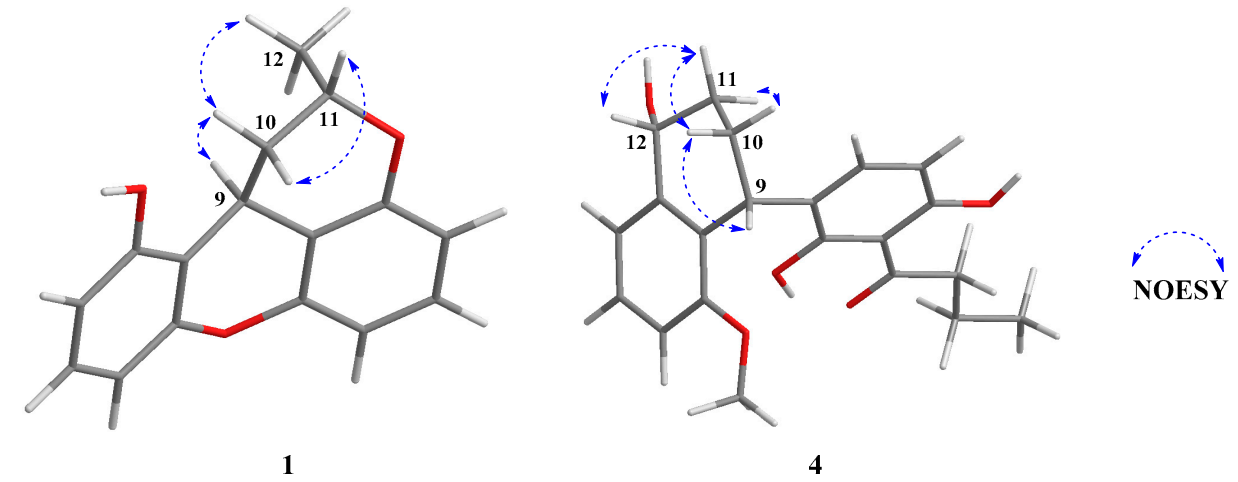

Figure 3. Energy-minimized 3D models of $\mathbf{1}$ and $\mathbf{4}$ with selected NOESY correlations.
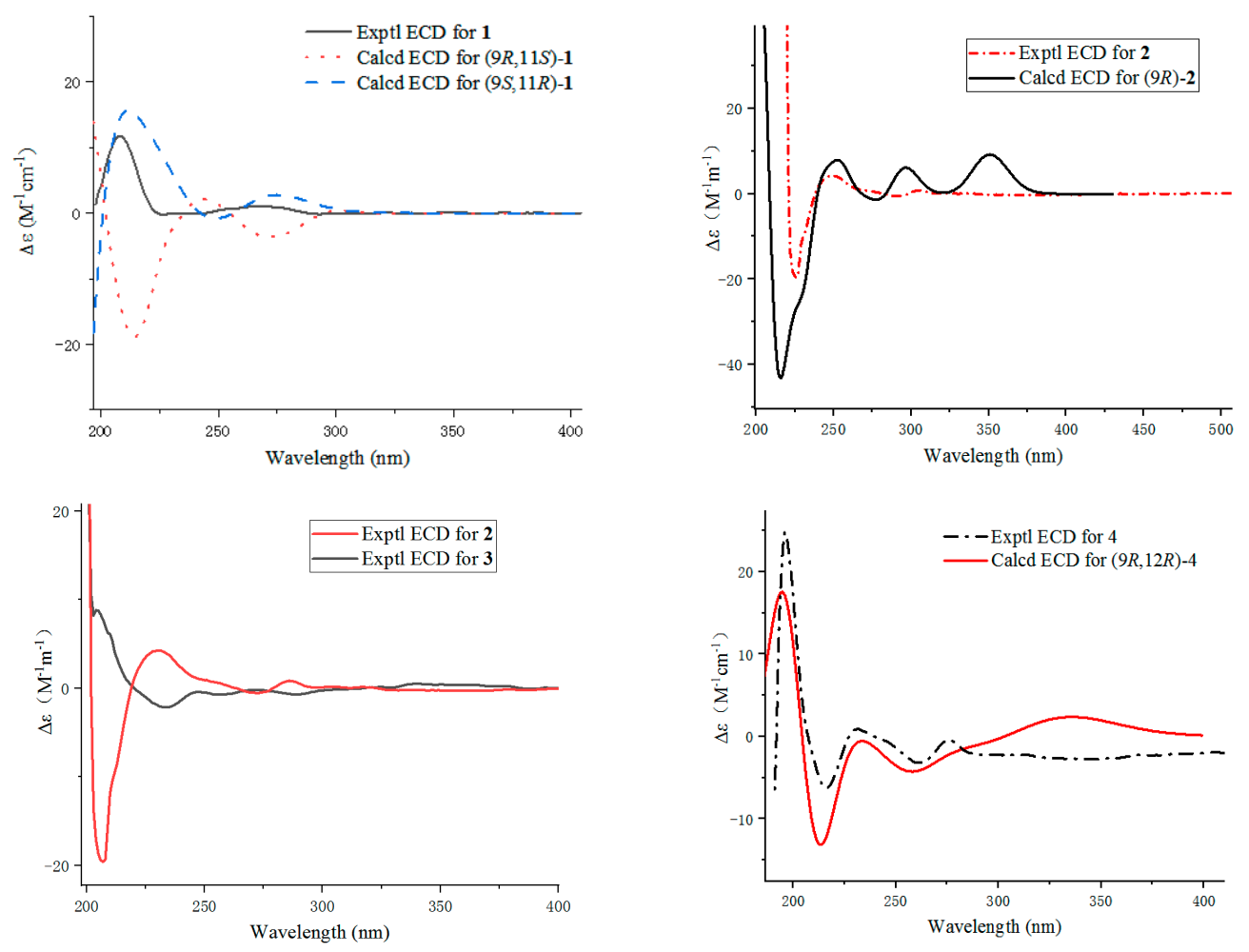

Figure 4. Experimental and calculated electronic circular dichroism (ECD) spectra of compounds 1-4.

Compound 2 was isolated as a colorless amorphous powder. The molecular formula of 2 was determined to be $\mathrm{C}_{20} \mathrm{H}_{22} \mathrm{O}_{5}$ (10 degrees of unsaturation) by HRESIMS (Figure S16). The ${ }^{1} \mathrm{H}$ and ${ }^{13} \mathrm{C}$ NMR data (Tables 1 and 2, Figures S9 and S10) revealed that 2 belongs to the 9-methylene-9H-xanthene class [10], and suggested a close structural relationship to 1 . The obvious differences in ${ }^{1} \mathrm{H}$ NMR spectrum were the disappearance of two aromatic protons signals at $\delta_{\mathrm{H}} 6.50 / \mathrm{H}-5$ and $\delta_{\mathrm{H}} 7.05 / \mathrm{H}-6$ in 2 . In addition, in the ${ }^{13} \mathrm{C}$ NMR spectra, the C-5/C-6 signals moved downfield $\delta_{\mathrm{C}} 110.2 / 127.9$ in 1 vs. $\delta_{\mathrm{C}}$ $110.7 / 157.3$ in 2 , indicating that the disappearance of two aromatic protons were respectively replaced by a butan-1-one unit at C-5 and a hydroxy group at C-6 in 2, which was further supported by HMBC 
(Figure S13). The existence of the butan-1-one unit was confirmed by HMBC correlations from $\mathrm{H}-14$ to C-5/C-13/C-16, H-15 to C-13/C-14, and H-16 to C-14/C-15.

Table 1. ${ }^{1} \mathrm{H}$ NMR data $(400 \mathrm{MHz}, \delta$ in ppm, $J$ in $\mathrm{Hz})$ for $\mathbf{1}-\mathbf{4}$.

\begin{tabular}{ccccc}
\hline Position & $\mathbf{1}^{a}$ & $\mathbf{2}^{\boldsymbol{b}}$ & $\mathbf{3}^{\boldsymbol{b}}$ & $\mathbf{4}^{\boldsymbol{b}}$ \\
\hline 2 & $6.55, \mathrm{dd}(8.0,0.8)$ & $6.35, \mathrm{dd}(8.0,0.8)$ & $6.35, \mathrm{dd}(8.0,0.8)$ & $6.81, \mathrm{~d}(8.0)$ \\
3 & $7.04, \mathrm{dd}(8.0,8.0)$ & $6.90, \mathrm{dd}(8.0,8.0)$ & $6.94, \mathrm{dd}(8.0,8.0)$ & $7.24, \mathrm{dd}(8.0,8.0)$ \\
4 & $6.58, \mathrm{dd}(8.0,0.8)$ & $6.26, \mathrm{dd}(8.0,0.8)$ & $6.29, \mathrm{dd}(8.0,0.8)$ & $7.06, \mathrm{~d}(8.0)$ \\
5 & $6.52, \mathrm{dd}(8.4,1.2)$ & & & \\
6 & $7.05, \mathrm{dd}(8.4,8.4)$ & & & \\
7 & $6.50, \mathrm{dd}(8.4,1.2)$ & $6.18, \mathrm{~d}(8.4)$ & $6.16, \mathrm{~d}(8.4)$ & $6.05, \mathrm{~d}(8.4)$ \\
8 & & $6.69, \mathrm{~d}(8.4)$ & $6.57, \mathrm{~d}(8.4)$ & $6.22, \mathrm{~d}(8.4)$ \\
9 & $3.99, \mathrm{dd}(12.4,4.0)$ & $4.52, \mathrm{dd}(10.4,8.0)$ & $4.50, \mathrm{dd}(7.6,1.2)$ & $4.63, \mathrm{~m}$ \\
$10 \mathrm{a}$ & $1.79, \mathrm{td}(12.4,6.4)$ & $1.49, \mathrm{td}(13.6,10.4)$ & $1.76, \mathrm{ddd}(13.6,7.6,4.4)$ & $1.81, \mathrm{~m}$ \\
$10 \mathrm{~b}$ & $3.17, \mathrm{ddd}(13.2,4.0,1.6)$ & $2.44, \mathrm{ddd}(13.6,8.0,1.6)$ & $2.06, \mathrm{td}(13.6,1.2)$ & $2.22, \mathrm{~m}$ \\
11 & $4.64, \mathrm{~m}$ & $4.04, \mathrm{~m}$ & $3.82, \mathrm{~m}$ & $1.74, \mathrm{~m}$ \\
12 & $1.39, \mathrm{~d}(6.4)$ & $1.28, \mathrm{~d}(6.4)$ & $1.25, \mathrm{~d}(6.4)$ & $4.72, \mathrm{~m}$ \\
14 & & $3.11, \mathrm{t}(7.2)$ & $3.13, \mathrm{t}(7.2)$ & $3.12, \mathrm{t}(7.2)$ \\
15 & & $1.71, \mathrm{~m}$ & $1.73, \mathrm{~m}$ & $1.72, \mathrm{~m}$ \\
16 & & $0.98, \mathrm{t}(7.2)$ & $0.99, \mathrm{t}(7.2)$ & $0.99, \mathrm{t}(7.2)$ \\
17 & & & $3.57, \mathrm{~s}$ \\
\hline
\end{tabular}

${ }^{a} \mathrm{DMSO}-d_{6}{ }^{b} \mathrm{CD}_{3} \mathrm{OD}$.

Table 2. ${ }^{13} \mathrm{C}$ NMR data (100 MHz, $\delta$ in ppm) for $\mathbf{1 - 4}$.

\begin{tabular}{|c|c|c|c|c|}
\hline Position & $1^{a}$ & $2^{b}$ & $3^{b}$ & $4^{b}$ \\
\hline 1 & $156.9, \mathrm{C}$ & $159.7, \mathrm{C}$ & $159.9, \mathrm{C}$ & $141.6, \mathrm{C}$ \\
\hline 2 & $107.0, \mathrm{CH}$ & $109.3, \mathrm{CH}$ & $108.7, \mathrm{CH}$ & $110.8, \mathrm{CH}$ \\
\hline 3 & $127.8, \mathrm{CH}$ & $128.2, \mathrm{CH}$ & $128.6, \mathrm{CH}$ & $128.3, \mathrm{CH}$ \\
\hline 4 & $110.4, \mathrm{CH}$ & 108.7, CH & 107.4, CH & 123.3, CH \\
\hline $4 a$ & 152.3, C & 157.3, C & $158.3, \mathrm{C}$ & $158.3, \mathrm{C}$ \\
\hline $4 b$ & $150.1, \mathrm{C}$ & $161,9, \mathrm{C}$ & $161,9, \mathrm{C}$ & 162.1, C \\
\hline 5 & $110.2, \mathrm{CH}$ & 110.7, C & $110.9, \mathrm{C}$ & $110.9, \mathrm{C}$ \\
\hline 6 & $127.9, \mathrm{CH}$ & 157.3, C & $159.9, \mathrm{C}$ & $159.7, \mathrm{C}$ \\
\hline 7 & $106.5, \mathrm{CH}$ & 107.0, $\mathrm{CH}$ & 106.0, CH & $105.8, \mathrm{CH}$ \\
\hline 8 & $154.3, \mathrm{C}$ & $134.4, \mathrm{CH}$ & 136.6, $\mathrm{CH}$ & $135.6, \mathrm{CH}$ \\
\hline $8 a$ & 109.3, C & $126.2, \mathrm{C}$ & 125.3, C & $125.4, \mathrm{C}$ \\
\hline $8 b$ & $109.1, \mathrm{C}$ & $114.3, \mathrm{C}$ & $111.9, \mathrm{C}$ & $128.9, \mathrm{C}$ \\
\hline 9 & $22.3, \mathrm{CH}$ & $31.8, \mathrm{CH}$ & $30.5, \mathrm{CH}$ & $32.3, \mathrm{CH}$ \\
\hline 10 & $33.0, \mathrm{CH}_{2}$ & $40.4, \mathrm{CH}_{2}$ & $36.1, \mathrm{CH}_{2}$ & $23.9, \mathrm{CH}_{2}$ \\
\hline 11 & $71.7, \mathrm{CH}$ & $73.4, \mathrm{CH}$ & $68.7, \mathrm{CH}$ & $28.2, \mathrm{CH}_{2}$ \\
\hline 12 & 20.7, $\mathrm{CH}_{3}$ & 21.6, $\mathrm{CH}_{3}$ & 21.7, $\mathrm{CH}_{3}$ & $67.9, \mathrm{CH}$ \\
\hline 13 & & $209.7, \mathrm{C}$ & $209.8, C$ & $209.9, \mathrm{C}$ \\
\hline 14 & & 47.6, $\mathrm{CH}_{2}$ & 47.6, $\mathrm{CH}_{2}$ & 47.2, $\mathrm{CH}_{2}$ \\
\hline 15 & & $19.1, \mathrm{CH}_{2}$ & $19.1, \mathrm{CH}_{2}$ & $19.2, \mathrm{CH}_{2}$ \\
\hline 16 & & $14.3, \mathrm{CH}_{3}$ & $14.3, \mathrm{CH}_{3}$ & $14.3, \mathrm{CH}_{3}$ \\
\hline 17 & & & & $59.9, \mathrm{OCH}_{3}$ \\
\hline
\end{tabular}

${ }^{a}$ DMSO- $d_{6}{ }^{b} \mathrm{CD}_{3} \mathrm{OD}$.

Furthermore, the oxygen-bridge between C-11 to C-8 in $\mathbf{1}$ was broken in $\mathbf{2}$. The C-8 signal moved high-field significantly at $\delta_{\mathrm{C}} 134.4$ in $\mathbf{2}$ vs. $\delta_{\mathrm{C}} 154.3$ in $\mathbf{1}$ in the ${ }^{13} \mathrm{C}$ NMR spectrum, and the H-8 signal at $\delta_{\mathrm{H}} 6.69$ in 2 in the ${ }^{1} \mathrm{H}$ NMR spectrum, indicating that oxygen function at C-8 in 1 was replaced by an aromatic proton in 2, which was confirmed by HMBC correlations (Figure 2) of H-7 to C-5/C-8a, H-8 to C-4b/C-6/C-9, H-9 to C-4a/C-4b, H-10 to C-8a/C-8b, H-11 to C-9, and $\mathrm{H}_{3}-12$ to C-10/C-11. The ${ }^{1} \mathrm{H}_{-}{ }^{1} \mathrm{H}$ COSY (Figure S14) and HMBC spectra allowed the complete assignment of 2 . The absolute configuration of C-9 in 2 was resolved by comparing experimental and calculated ECD spectra using 
TDDFT (Figure 4) [11]. The absolute configuration of C-11 was determined by making MTPA esters of 2 [12], and the differences in ${ }^{1} \mathrm{H}$ NMR (Figures S33 and S35) chemical shifts between (S)- and (R)-MTPA esters $\left(\Delta \delta=\delta_{S}-\delta_{R}\right)$ (Figure 5) were calculated to assign the absolute configuration of C-11 to be $R$. Thus, the absolute configuration of 2 was established as $9 R, 11 R$, and it was named penicixanthene $\mathrm{B}$.

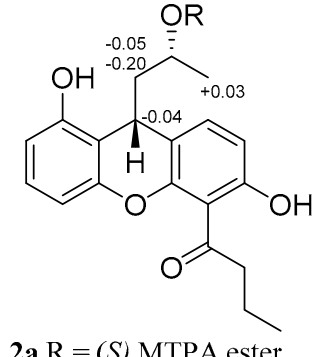

$\mathbf{2 a} \mathrm{R}=(S)$ MTPA ester $\mathbf{2 b} \mathrm{R}=(R)$ MTPA ester

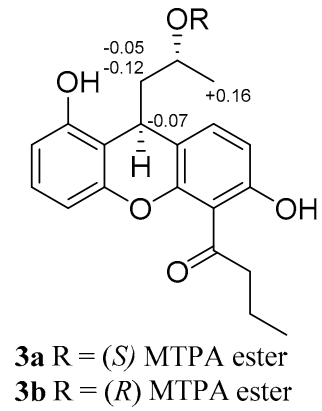

Figure 5. Reactions of compounds 2 and 3 with Mosher esters.

Compound 3, isolated as a colorless amorphous powder, was evidenced to have a molecular formula of $\mathrm{C}_{20} \mathrm{H}_{22} \mathrm{O}_{5}$ (10 degrees of unsaturation) from its HRESIMS data (Figure S24). The similarities in the NMR data (Figures S17 and S18) for 3 and 2 suggested that 3 was structurally similar to 2, with the main differences being the chemical shifts of C-8b/C-9/C-10 (Table 2) and the coupling constants of H-9/H-10 (Table 1), and as indicated by the small coupling constant $J_{9,10}=1.2 \mathrm{~Hz}$ and $2 \mathrm{D}$ NMR data in 3 (vs. the coupling constant $J_{9,10}=8.0 \mathrm{~Hz}$ in 2) [13], implying that the H-9 orientation of 3 was different from that of $\mathbf{2}$. The absolute configuration of C-9 in $\mathbf{3}$ was established by comparison of experimental and calculated electronic circular dichroism (ECD) data [11]. The experimental spectrum of 3 showed the opposite Cotton effect with the experimental results of 2 recorded in $\mathrm{MeOH}$ (Figure 4), which supported that the absolute configuration of C-9 in 3 was $9 S$. The absolute configuration of C-11 was determined by making MTPA esters of 3 [12]. The differences in ${ }^{1} \mathrm{H}$ NMR (Figures S37 and S39) chemical shifts between $(S)$ - and $(R)$-MTPA esters $\left(\Delta \delta=\delta_{S}-\delta_{R}\right)$ (Figure 5) were calculated to assign the absolute configuration of $\mathrm{C}-11$ to be $R$. Thus, the absolute configuration of 3 was assigned as $9 S$, $11 R$, and the structure of 3 was defined as penicixanthene $C$.

Compound 4 was obtained as white amorphous powder, and the molecular formula was deduced to be $\mathrm{C}_{21} \mathrm{H}_{24} \mathrm{O}_{5}$ on the basis of HRESIMS (Figure S32), implying 10 degrees of unsaturation. Analysis of the ${ }^{1} \mathrm{H}$ NMR spectrum (Table 1, Figure S25) displayed signals corresponding to five olefinic protons signal at $\delta_{\mathrm{H}} 7.24(\mathrm{dd}, J=8.0,8.0 \mathrm{~Hz}, \mathrm{H}-3), 7.06(\mathrm{~d}, J=8.0 \mathrm{~Hz}, \mathrm{H}-4), 6.81(\mathrm{~d}, J=8.0 \mathrm{~Hz}, \mathrm{H}-2), 6.22(\mathrm{~d}$, $J=8.4 \mathrm{~Hz}, \mathrm{H}-8)$, and $6.05(\mathrm{~d}, J=8.4 \mathrm{~Hz}, \mathrm{H}-7)$; two methine signals at $\delta_{\mathrm{H}} 4.72(\mathrm{~m}, \mathrm{H}-12)$ and $4.63(\mathrm{~m}, \mathrm{H}-9)$; four methylene groups at $\delta_{\mathrm{H}} 3.12(\mathrm{t}, J=7.2 \mathrm{~Hz}, \mathrm{H}-14), 2.22(\mathrm{~m}, \mathrm{H}-10 \mathrm{~b}), 1.81$ (m H-10a), 1.74 (m, H-11), and 1.72 (m, H-15); and two methyl groups at $\delta_{\mathrm{H}} 3.57(\mathrm{~s}, \mathrm{H}-17)$ and $0.99(\mathrm{t}, J=7.2 \mathrm{~Hz}, \mathrm{H}-16)$. The ${ }^{13} \mathrm{C}$ NMR spectrum (Table 2, Figure S26) displayed 21 signals, which were classified by DEPT (Figure S27) and HMQC spectra (Figure S28) as twelve $\mathrm{sp}^{2}$-hybridized carbons $\left(\delta_{\mathrm{C}} 162.1,159.7,158.3,141.6,135.6\right.$, $128.9,128.3,125.4,123.3,110.9,110.8$, and 105.8) indicating the presence of two benzene rings, two $\mathrm{sp}^{3}$ methine groups $\left(\delta_{\mathrm{C}} 67.9\right.$ and 32.3$)$, four $\mathrm{sp}^{3}$ methylene groups $\left(\delta_{\mathrm{C}} 47.2,28.2,23.9\right.$, and 19.2$)$, and two methyl groups $\left(\delta_{C} 59.9\right.$ and 14.3). The above NMR spectroscopic data indicated the presence of a structure similar to nodulisporin F [13] with two subunits. One of the subunits was similar to 5 [14], isolated from the same source. The other subunit showed signals corresponding to the naphthalene part. The locations of connection between the two units at C-8a/C-9 were evidenced from HMBC correlations (Figure 2, Figure S29) of $\mathrm{H}-9$ to $\mathrm{C}-4 \mathrm{a} / \mathrm{C}-4 \mathrm{~b} / \mathrm{C}-8 / \mathrm{C}-8 \mathrm{a} / \mathrm{C}-8 \mathrm{~b}$, as well as from H-8 to C-9. Based on the above data, the naphthalene part of 4 was linked to a 1-(2,6-dihydroxyphenyl)-butan-1-one moiety in para-position to the phenol group (at C-9). In addition, the C-4a and C-12 in 4 were replaced by a methoxyl group and a hydroxy group, respectively. 
The relative configuration of 4 was based on the NOESY (Figure S31) correlations, as indicated in Figure 3. The NOESY correlations of $\mathrm{H}-9$ to $\mathrm{H}-10 \mathrm{a}, \mathrm{H}-11 \mathrm{a}$, and $\mathrm{H}-12$, as well as $\mathrm{H}-10 \mathrm{~b}$ to $\mathrm{H}-11 \mathrm{~b}$, indicated that H-9, H-10a, H-11a, and H-12 were on the contrary side of the H-10b and H-11b. The absolute configuration of 4 was elucidated as $9 R, 12 R$ by comparing its experimental ECD spectrum to the calculated spectrum (Figure 4) [11]. The structure of 4 was assigned, named as penicixanthene D.

\subsection{Biological Activity}

Compounds 1-5 were examined for insecticidal activity. In the test, we set up three parallel trials. Compounds 2 and $\mathbf{3}$ showed growth inhibition activities against newly hatched larvae of Helicoverpa armigera Hubner with the $\mathrm{IC}_{50}$ values 100 and $200 \mu \mathrm{g} / \mathrm{mL}$, respectively. Azadirachtin was used as positive control with the $\mathrm{IC}_{50}$ value of $25 \mu \mathrm{g} / \mathrm{mL}$. Compounds 1, 3, and 4 showed insecticidal activity against newly hatched larvae of Culex quinquefasciatus with $\mathrm{LC}_{50}$ values of $38.5( \pm 1.16), 11.6( \pm 0.58)$ and $20.5( \pm 1) \mu \mathrm{g} / \mathrm{mL}$, respectively. Azadirachtin was used as positive control with the $\mathrm{LC}_{50}$ value of 8.8 $( \pm 0.58) \mu \mathrm{g} / \mathrm{mL}$ (Table 3).

Table 3. Biological activities of 1-5.

\begin{tabular}{|c|c|c|}
\hline \multirow{2}{*}{ Compounds } & $\mathrm{IC}_{50}(\mu \mathrm{g} / \mathrm{mL})$ & $\mathrm{LC}_{50}(\mu \mathrm{g} / \mathrm{mL})$ \\
\hline & Helicoverpa armigera Hubner & Culex quinquefasciatus \\
\hline 1 & $>200$ & $38.5( \pm 1.16)$ \\
\hline 2 & 100 & $>80$ \\
\hline 3 & 200 & $11.6( \pm 0.58)$ \\
\hline 4 & $>200$ & $23.5( \pm 1)$ \\
\hline 5 & $>200$ & $>80$ \\
\hline Azadirachtin $^{a}$ & 25 & $8.8( \pm 0.58)$ \\
\hline
\end{tabular}

${ }^{a}$ Azadirachtin was used as a positive control.

\section{Materials and Methods}

\subsection{General Experimental Procedures}

Optical rotations were measured on a JASCO P-1020 digital polarimeter (JASCO, Tokyo, Japan). IR spectra were recorded on a Thermo Nicolet 6700 (using KBr disks) spectrophotometer (Thermo, Madison, USA). 1D and 2D NMR spectra were measured on a Bruker AV-400 spectrometer with TMS as the internal standard (Bruker Corporation, Fällanden, Switzerland) (The PULPROG for testing NOESY was noesygpphpp, the temperature was $300 \mathrm{~K}$, and the mix time of NOESY was 0.3 s). HRESIMS spectra were obtained on a Q-TOF Ultima Global GAA076 LC mass spectrometer (Waters, Milford, MA, USA). Preparative HPLC was used for an Agilent 1260 prep-HPLC system with an Agilent Eclipse XDB-C18 column ( $250 \mathrm{~mm} \times 9.4 \mathrm{~mm}, 7 \mu \mathrm{m}$, Agilent Corporation, Santa Clara, CA, USA). The other experimental procedures were performed as reported previously [6].

\subsection{Fungal Materials}

The fungal strain Penicillium sp. JY246 was isolated from the stem of mangrove Ceriops tagal, collected in the South China Sea in July 2016. The fungus was identified according to its morphological characteristics and by comparison of the internal transcribed spacer (ITS) sequence amplification, primer pair ITS1 and ITS4 and sequencing of the ITS region. The sequence data has been submitted to GenBank with the accession number MK050979, and identified as Penicillium.

The fungal strain was cultivated in $20 \mathrm{~L}$ potato glucose liquid medium ( $15 \mathrm{~g}$ of glucose and $30 \mathrm{~g}$ of sea salt in $1 \mathrm{~L}$ of potato infusion, in $1 \mathrm{~L}$ Erlenmeyer flasks each containing $300 \mathrm{~mL}$ of culture broth) at $25^{\circ} \mathrm{C}$ without shaking for 4 weeks. 


\subsection{Extraction and Isolation}

The fungal cultures were filtered through cheesecloth, and the filtrate was extracted with EtOAc $(3 \times 20 \mathrm{~L}, 24 \mathrm{~h}$ each). The organic extracts were concentrated in vacuo to yield an oily residue $(23.6 \mathrm{~g})$, which was subjected to silica gel column chromatography (CC) (petroleum ether, EtOAc $v / v$, gradient 100:0-0:100) to generate five fractions (Fr. 1-Fr. 5). Fraction Fr. 4 (5 g) was separated by silica gel CC and eluted with petroleum ether-EtOAc (from 3:1 to 0:1) to afford four subfractions (4a-4d). Subfraction $\mathbf{4 b}$ were further separated by semi-preparative $\mathrm{HPLC}\left(\mathrm{MeOH}-\mathrm{H}_{2} \mathrm{O}, 45: 55, v / v\right)$ to obtain $\mathbf{1}(6.0 \mathrm{mg}), \mathbf{4}$ $(4.5 \mathrm{mg})$, and $5(5.0 \mathrm{mg})$, and subfraction $4 \mathrm{c}$ was further separated by semi-preparative HPLC with $\mathrm{MeOH}-\mathrm{H}_{2} \mathrm{O}(35: 65 \mathrm{v} / \mathrm{v})$ to give $2(3.3 \mathrm{mg})$ and $3(3.5 \mathrm{mg})$.

Penicixanthene A (1): white amorphous powder. $[\alpha]_{\mathrm{D}}^{24}-10.7\left(c=0.02, \mathrm{CHCl}_{3}\right) . \mathrm{CD}\left(c 2 \times 10^{-4} \mathrm{~mol} / \mathrm{L}\right.$, $\mathrm{MeOH}) \lambda_{\max }(\Delta \varepsilon) 211(+11.8), 242(-0.1), 269(+1.1) \mathrm{nm}$; IR (KBr) $v_{\max } 3405,2923,1747,1740,1230$, 1064, $756 \mathrm{~cm}^{-1} ;{ }^{1} \mathrm{H}$ and ${ }^{13} \mathrm{C}$ NMR see Tables 1 and 2; HRESIMS $\mathrm{m} / z 255.1012[\mathrm{M}+\mathrm{H}]^{+}$(calcd. For $\left.\mathrm{C}_{16} \mathrm{H}_{15} \mathrm{O}_{3}, 255.1016\right)$.

Penicixanthene B (2): white amorphous powder. $[\alpha]_{\mathrm{D}}^{24}-9.5\left(c=0.02, \mathrm{CHCl}_{3}\right) . \mathrm{CD}\left(c 2 \times 10^{-4} \mathrm{~mol} / \mathrm{L}\right.$, $\mathrm{MeOH}) \lambda_{\max }(\Delta \varepsilon) 207$ (-19.6), $232(+4.2), 252(+0.8), 286(+0.8) \mathrm{nm} ; \mathrm{IR}(\mathrm{KBr}) v_{\max } 3402,2944,1747,1410$, 1250, 1064, $818 \mathrm{~cm}^{-1} ;{ }^{1} \mathrm{H}$ and ${ }^{13} \mathrm{C}$ NMR see Tables 1 and 2; HRESIMS $\mathrm{m} / \mathrm{z} 343.1537[\mathrm{M}+\mathrm{H}]^{+}$(calcd. for $\left.\mathrm{C}_{20} \mathrm{H}_{23} \mathrm{O}_{5}, 343.1540\right)$.

Penicixanthene $\mathrm{C}(3)$ : white amorphous powder. $[\alpha]_{\mathrm{D}}^{24}+10.7\left(c=0.10, \mathrm{CHCl}_{3}\right) . \mathrm{CD}\left(c 2 \times 10^{-4} \mathrm{~mol} / \mathrm{L}\right.$, $\mathrm{MeOH}) \lambda_{\max }(\Delta \varepsilon) 207(+8.3), 232(-2.1), 252(-0.7), 286(-0.7) \mathrm{nm}$; IR (KBr) $v_{\max } 3405,2943,1740,1413$, 1255, 1061, $820 \mathrm{~cm}^{-1} ;{ }^{1} \mathrm{H}$ and ${ }^{13} \mathrm{C}$ NMR see Tables 1 and 2; HRESIMS $\mathrm{m} / \mathrm{z} 343.1537[\mathrm{M}+\mathrm{H}]^{+}$(calcd. for $\left.\mathrm{C}_{20} \mathrm{H}_{23} \mathrm{O}_{5}, 343.1540\right)$.

Penicixanthene $\mathrm{D}(4)$ : white amorphous powder. $[\alpha]_{\mathrm{D}}^{24}+30.7\left(c=0.10, \mathrm{CHCl}_{3}\right) . \mathrm{CD}\left(c 2 \times 10^{-4} \mathrm{~mol} / \mathrm{L}\right.$, $\mathrm{MeOH}) \lambda_{\max }(\Delta \varepsilon) 196(+25.1), 215(-5.2), 231(+1.9), 276(+0.5) \mathrm{nm}$; IR (KBr) $v_{\max }$ 3265, 1631, $1237 \mathrm{~cm}^{-1}$; ${ }^{1} \mathrm{H}$ and ${ }^{13} \mathrm{C}$ NMR see Tables 1 and 2; HRESIMS $m / z 357.1700[\mathrm{M}+\mathrm{H}]^{+}$(calcd. for $\mathrm{C}_{21} \mathrm{H}_{25} \mathrm{O}_{5} 357.1697$ )

\subsection{Preparation of (S)- and (R)-MTPA Ester Derivatives of Compounds 2 and 3}

Preparations of $(S)$ - and (R)-MTPA ester derivatives of $\mathbf{2}$ and $\mathbf{3}$ were performed as described previously [6].

S-MTPA ester of $2(\mathbf{2 a}):{ }^{1} \mathrm{H}$ NMR $\left(\mathrm{CDCl}_{3}, 400 \mathrm{MHz}\right) \delta_{\mathrm{H}}: 7.23(1 \mathrm{H}, \mathrm{d}, J=8.4 \mathrm{~Hz}, \mathrm{H}-8), 7.15(1 \mathrm{H}, \mathrm{t}$, $J=6.8 \mathrm{~Hz}, \mathrm{H}-3), 6.96(1 \mathrm{H}, \mathrm{dd}, J=8.8,0.8 \mathrm{~Hz}, \mathrm{H}-2), 6.81(1 \mathrm{H}, \mathrm{d}, J=8.4 \mathrm{~Hz}, \mathrm{H}-7), 6.46(1 \mathrm{H}, \mathrm{dd}, J=8.8$, $0.8 \mathrm{~Hz}, \mathrm{H}-4), 5.34(1 \mathrm{H}, \mathrm{m}, \mathrm{H}-11), 4.12(1 \mathrm{H}, \mathrm{m}, \mathrm{H}-9), 3.59$ (2H, m, H-14), $2.53(1 \mathrm{H}, \mathrm{m}, \mathrm{H}-10 \mathrm{~b}), 2.01(2 \mathrm{H}, \mathrm{m}$, $\mathrm{H}-15), 1.74(1 \mathrm{H}, \mathrm{m}, \mathrm{H}-10 \mathrm{a}), 1.17(3 \mathrm{H}, \mathrm{d}, J=6.0 \mathrm{~Hz}, \mathrm{H}-12), 0.77$ (3H, t $, J=7.2 \mathrm{~Hz}, \mathrm{H}-16)$. ESI-MS m/z 773.1 $[\mathrm{M}-\mathrm{H}]^{-}$.

R-MTPA ester of $\mathbf{2}(\mathbf{2 b}):{ }^{1} \mathrm{H}$ NMR $\left(\mathrm{CDCl}_{3}, 400 \mathrm{MHz}\right) \delta_{\mathrm{H}}: 7.29(1 \mathrm{H}, \mathrm{m}, \mathrm{H}-8), 7.10(1 \mathrm{H}, \mathrm{m}, \mathrm{H}-3), 6.99$ (1H, m, H-2), $6.46(1 \mathrm{H}, \mathrm{m}, \mathrm{H}-7), 6.23(1 \mathrm{H}, \mathrm{m}, \mathrm{H}-4), 5.32(1 \mathrm{H}, \mathrm{m}, \mathrm{H}-11), 4.08$ (1H, m, H-9), 3.58 (2H, m, H-14), 2.33 (1H, m, H-10b), 1.99 (2H, m, H-15), 1.69 (1H, m, H-10a), 1.20 (3H, m, H-12), 0.72 (3H, m, H-16). ESI-MS $m / z 773.1[\mathrm{M}-\mathrm{H}]^{-}$.

S-MTPA ester of 3 (3a): ${ }^{1} \mathrm{H}$ NMR $\left(\mathrm{CDCl}_{3}, 400 \mathrm{MHz}\right) \delta_{\mathrm{H}}: 7.35(1 \mathrm{H}, \mathrm{m}, \mathrm{H}-8), 7.30(1 \mathrm{H}, \mathrm{m}, \mathrm{H}-3), 6.81$ (1H, m, H-2), 6.69 (1H, m, H-7), 6.49 (1H, m, H-4), $5.34(1 \mathrm{H}, \mathrm{m}, \mathrm{H}-11), 4.52(1 \mathrm{H}, \mathrm{m}, \mathrm{H}-9), 3.58$ (2H, m, H-14), 2.61 (1H, m, H-10b), $2.11(2 \mathrm{H}, \mathrm{m}, \mathrm{H}-15), 2.01(1 \mathrm{H}, \mathrm{m}, \mathrm{H}-10 \mathrm{a}), 1.30(3 \mathrm{H}, \mathrm{d}, J=4.8 \mathrm{~Hz}, \mathrm{H}-12), 0.74$ $(3 \mathrm{H}, \mathrm{t}, J=7.2 \mathrm{~Hz}, \mathrm{H}-16)$. ESI-MS $m / z 773.1[\mathrm{M}-\mathrm{H}]^{-}$.

R-MTPA ester of $3 \mathbf{3}(\mathbf{3 b}):{ }^{1} \mathrm{H}$ NMR $\left(\mathrm{CDCl}_{3}, 400 \mathrm{MHz}\right) \delta_{\mathrm{H}}: 7.30(1 \mathrm{H}, \mathrm{m}, \mathrm{H}-8), 7.07(1 \mathrm{H}, \mathrm{m}, \mathrm{H}-3), 6.96$ (1H, m, H-2), 6.56 (1H, m, H-7), 6.36 (1H, m, H-4), 5.35 (1H, m, H-11), 4.59 (1H, m, H-9), 3.55 (2H, m, $\mathrm{H}-14), 2.56$ (1H, m, H-10b), $2.10(2 \mathrm{H}, \mathrm{m}, \mathrm{H}-15), 1.89$ (1H, m, H-10a), 1.31 (3H, d, J = 6.0 Hz, H-12), 0.74 $(3 \mathrm{H}, \mathrm{t}, J=6.4 \mathrm{~Hz}, \mathrm{H}-16)$. ESI-MS $m / z 773.1[\mathrm{M}-\mathrm{H}]^{-}$.

\subsection{Computational Section}

As previously reported $[6,15,16]$. 


\subsection{Insecticidal Activities against Newly Hatched Larvae of Helicoverpa armigera Hubner}

Insecticidal activity against newly hatched larvae of $H$. armigera Hubner was evaluated according to the previously reported methods [6]. Newly hatched larvae were raised under $25 \pm 1^{\circ} \mathrm{C}$ and a relative humidity of $80 \%$. DMSO was used as the negative control, azadirachtin was used as the positive control, and artificial diet was used as the blank control. The number of dead larvae was recorded on the 2 nd, 4 th, 6th, and 8th day after treatment, respectively [17].

\subsection{Insecticidal Activities against Newly Hatched Larvae of Culex quinquefasciatus}

Insecticidal activity against newly hatched larvae of C. quinquefasciatus was evaluated according to the previously reported methods $[17,18]$. DMSO was used as the negative control, azadirachtin was used as the positive control, and $10 \mathrm{~mL}$ dechlorinated water was used as the blank control. The number of dead larvae was recorded on the 1st, 2 nd, 3rd, and 4th day after treatment, respectively.

\section{Conclusions}

In summary, four new xanthene derivatives, penicixanthenes A-D (1-4), along with one known compound 5, were obtained from the mangrove-derived fungus Penicillium sp. JY246. Furthermore, the absolute configurations of 2 and 3 were determined by modified Mosher's method and calculated electronic circular dichroism data. Compounds 2 and $\mathbf{3}$ showed growth inhibition activity against newly hatched larvae of $H$. armigera Hubner with the $\mathrm{IC}_{50}$ values 100 and $200 \mu \mathrm{g} / \mathrm{mL}$, respectively. Compounds 1, 3, and 4 showed insecticidal activity against newly hatched larvae of C. quinquefasciatus with $\mathrm{LC}_{50}$ values of $38.5( \pm 1.16), 11.6( \pm 0.58)$, and $20.5( \pm 1) \mu \mathrm{g} / \mathrm{mL}$, respectively.

Supplementary Materials: The following are available online at http://www.mdpi.com/1660-3397/17/12/649/s1, ${ }^{1} \mathrm{H}$ NMR, ${ }^{13} \mathrm{C}$ NMR, DEPT, HMQC, COSY, HMBC, NOESY, and HRESIMS spectra of compounds 1-4. Figure S1: ${ }^{1} \mathrm{H}$ NMR (DMSO- $d_{6}, 400 \mathrm{MHz}$ ) spectrum of 1 . Figure S2: ${ }^{13} \mathrm{C}$ NMR (DMSO- $d_{6}, 100 \mathrm{MHz}$ ) spectrum of 1 . Figure S3: DEPT (DMSO- $\left.d_{6}, 100 \mathrm{MHz}\right)$ spectrum of 1 . Figure S4: HMQC spectrum of 1 . Figure S5: HMBC spectrum of 1. Figure S6: ${ }^{1} \mathrm{H}-{ }^{1} \mathrm{H}$ COSY spectrum of $\mathbf{1}$. Figure S7: NOESY spectrum of 1. Figure S8: HRESIMS spectrum of 1. Figure S9: ${ }^{1} \mathrm{H}$ NMR $\left(\mathrm{CD}_{3} \mathrm{OD}, 400 \mathrm{MHz}\right)$ spectrum of 2. Figure $\mathrm{S} 10:{ }^{13} \mathrm{C} \mathrm{NMR}\left(\mathrm{CD}_{3} \mathrm{OD}, 100 \mathrm{MHz}\right)$ spectrum of 2. Figure S11: DEPT $\left(\mathrm{CD}_{3} \mathrm{OD}, 100 \mathrm{MHz}\right)$ spectrum of 2. Figure S12: HMQC spectrum of 2. Figure S13: HMBC spectrum of 2. Figure S14: ${ }^{1} \mathrm{H}-1{ }^{1} \mathrm{H}$ COSY spectrum of 2. Figure S15: NOESY spectrum of 2. Figure S16: HRESIMS spectrum of 2. Figure S17: ${ }^{1} \mathrm{H}$ NMR $\left(\mathrm{CD}_{3} \mathrm{OD}, 400 \mathrm{MHz}\right)$ spectrum of 3. Figure $\mathrm{S} 18:{ }^{13} \mathrm{C} \mathrm{NMR}\left(\mathrm{CD}_{3} \mathrm{OD}, 100 \mathrm{MHz}\right)$ spectrum of 3. Figure S19: DEPT ( $\left.\mathrm{CD}_{3} \mathrm{OD}, 100 \mathrm{MHz}\right)$ spectrum of 3. Figure S20: HMQC spectrum of 3. Figure S21: HMBC spectrum of 3. Figure S22: ${ }^{1} \mathrm{H}^{-1} \mathrm{H}$ COSY spectrum of 3. Figure S23: NOESY spectrum of 3. Figure S24: HRESIMS spectrum of 3. Figure S25: ${ }^{1} \mathrm{H}$ NMR $\left(\mathrm{CD}_{3} \mathrm{OD}, 400 \mathrm{MHz}\right)$ spectrum of 4 . Figure S26: ${ }^{13} \mathrm{C}$ NMR $\left(\mathrm{CD}_{3} \mathrm{OD}\right.$, $100 \mathrm{MHz})$ spectrum of 4 . Figure S27: DEPT $\left(\mathrm{CD}_{3} \mathrm{OD}, 100 \mathrm{MHz}\right)$ spectrum of 4 . Figure S28: HMQC spectrum of 4. Figure S29: HMBC spectrum of 4. Figure S30: COSY spectrum of 4. Figure S31: NOESY spectrum of 4. Figure S32: HRESIMS spectrum of 4. Figure S33: ${ }^{1} \mathrm{H} \mathrm{NMR}\left(\mathrm{CDCl}_{3}, 400 \mathrm{MHz}\right)$ of S-MTPA ester of 2a. Figure S34: ESIMS spectrum of 2a. Figure S35: ${ }^{1} \mathrm{H}$ NMR $\left(\mathrm{CDCl}_{3}, 400 \mathrm{MHz}\right)$ of $R$-MTPA ester of $\mathbf{2 b}$. Figure S36: ESIMS spectrum of 2b. Figure S37: ${ }^{1} \mathrm{H} \mathrm{NMR}\left(\mathrm{CDCl}_{3}, 400 \mathrm{MHz}\right)$ of $S$-MTPA ester of 3a. Figure S38: ESIMS spectrum of 3a. Figure S39: ${ }^{1} \mathrm{H} \mathrm{NMR}\left(\mathrm{CDCl}_{3}, 400 \mathrm{MHz}\right)$ of $R$-MTPA ester of $\mathbf{3 b}$. Figure S40: ESIMS spectrum of $\mathbf{3 b}$.

Author Contributions: M.B. performed the experiments for the isolation, structure elucidation, insecticidal activity, and antimicrobial evaluation, and prepared the manuscript; Y.-P.L. performed the 1D and 2D NMR experiments; X.-H.N. contributed to part of the structure determination; X.-M.Z. contributed to the optimization of fermentation; C.-J.Z. contributed to part of the structure determination and jointly supervised the research; G.-Y.C. supervised the research work and revised the manuscript.

Funding: This work was supported by the National Natural Science Foundation of China (Nos. 21662012 and 41866005), Program for Innovative Research Team in University (No. IRT-16R19), and the Key Research \& Development Program of Hainan (ZDYF2019116).

Conflicts of Interest: The authors declare no competing financial interest. 


\section{References}

1. Tang, J.W.; Kong, L.M.; Zu, W.Y.; Hu, K.; Li, X.N.; Yang, B.C.; Wang, W.G.; Sun, H.D.; Li, Y.; Puno, P.T. Isopenicins A-C: Two types of antitumor meroterpenoids from the plant endophytic fungus Penicillium sp. sh18. Org. Lett. 2019, 21,711-775. [CrossRef] [PubMed]

2. Liu, S.; Su, M.Z.; Song, S.J.; Hong, J.K.; Chung, H.Y.; Jung, J.H. An anti-inflammatory PPAR- $\gamma$ agonist from the jellyfish-derived fungus Penicillium chrysogenum J08NF-4. J. Nat. Prod. 2018, 81, 356-363. [CrossRef] [PubMed]

3. Liu, S.; Su, M.Z.; Song, S.J.; Jung, J.H. Marine-derived Penicillium species as producers of cytotoxic metabolites. Mar. Drugs 2017, 15, 329. [CrossRef] [PubMed]

4. Ariantari, N.P.; Ancheeva, E.; Wang, C.Y.; Mándi, A.; Knedel, T.O.; Kurtán, T.; Chaidir, C.; Müller, W.E.G.; Kassack, M.U.; Janiak, C.; et al. Indole diterpenoids from an endophytic Penicillium sp. J. Nat. Prod. 2019, 82, 1412-1423. [CrossRef] [PubMed]

5. Kong, F.D.; Fan, P.; Zhou, L.M.; Ma, Q.Y.; Xie, Q.Y.; Zheng, H.Z.; Zheng, Z.H.; Zhang, R.S.; Yuan, J.Z.; Dai, H.F.; et al. Penerpenes A-D, Four indole terpenoids with potent protein tyrosine phosphatase inhibitory activity from the marine-derived fungus Penicillium sp. KFD28. Org. Lett. 2019, 21, 4864-4867. [CrossRef] [PubMed]

6. Bai, M.; Zheng, C.J.; Huang, G.L.; Mei, R.Q.; Wang, B.; Luo, Y.P.; Zheng, C.; Niu, Z.G.; Chen, G.Y. Bioactive meroterpenoids and isocoumarins from the mangrove-derived fungus Penicillium sp. TGM112. J. Nat. Prod. 2019, 82, 1155-1164. [CrossRef] [PubMed]

7. Bie, Q.; Chen, C.M.; Yu, M.Y.; Guo, J.R.; Wang, J.P.; Liu, J.J.; Zhou, Y.; Zhu, H.C.; Zhang, Y.H. Dongtingnoids A-G: fusicoccane diterpenoids from a Penicillium species. J. Nat. Prod. 2019, 82, 80-86. [CrossRef] [PubMed]

8. Huang, G.L.; Zhou, X.M.; Bai, M.; Liu, Y.X.; Zhao, Y.L.; Luo, Y.P.; Niu, Y.Y.; Zheng, C.J.; Chen, G.Y. Dihydroisocoumarins from the mangrove-derived fungus Penicillium citrinum. Mar. Drugs 2016, 14, 177. [CrossRef] [PubMed]

9. Bai, M.; Huang, G.L.; Mei, R.Q.; Wang, B.; Luo, Y.P.; Nong, X.H.; Chen, G.Y.; Zheng, C.J. Bioactive lactones from the mangrove-derived fungus Penicillium sp. TGM112. Mar. Drugs 2019, 17, 433. [CrossRef] [PubMed]

10. Cao, J.Q.; Yao, Y.; Chen, H.; Qiao, L.; Zhou, Y.Z.; Pei, Y.H. A New xanthene from Blumea riparia. Chin. Chem. Lett. 2007, 18, 303-305. [CrossRef]

11. Choukchou-Braham, N.; Asakawa, Y.; Lepoittevin, J.P. Isolation, structure determination and synthesis of new dihydroisocoumarins from Ginkgo biloba L. Tetrahedron Lett. 1994, 35, 3949-3952. [CrossRef]

12. Kusumi, T.; Fujita, Y.; Ohtani, I.; Kakisawa, H. Anomaly in the modified Mosher's method: absolute configurations of some marine cembranolides. Tetrahedron Lett. 1991, 32, 2923-2926. [CrossRef]

13. Dai, J.Q.; Krohn, K.; Draeger, S.; Schulz, B. New naphthalene-chroman coupling products from the endophytic fungus, Nodulisporium sp. from Erica arborea. Eur. J. Org. Chem. 2009, 10, 1564-1569. [CrossRef]

14. Yang, L.J.; Liao, H.X.; Bai, M.; Huang, G.L.; Luo, Y.P.; Niu, Y.Y.; Zheng, C.J.; Chen, G.Y. One new cytochalasin metabolite isolated from a mangrovederived fungus Daldinia eschscholtzii HJ001. Nat. Prod. Res. 2018, 32, 208-213. [CrossRef] [PubMed]

15. Elnaggar, M.S.; Ebrahim, W.; Mándi, A.; Kurtán, T.; Müller, W.E.G.; Kalscheuer, R.; Singab, A.; Lin, W.H.; Liu, Z.; Proksch, P. Hydroquinone derivatives from the marine-derived fungus Gliomastix sp. RSC Adv. 2017, 7, 30640-30649. [CrossRef]

16. Ren, J.; Ding, S.S.; Zhu, A.; Cao, F.; Zhu, H.J. Bioactive azaphilone derivatives from the fungus Talaromyces aculeatus. J. Nat. Prod. 2017, 80, 2199-2203. [CrossRef] [PubMed]

17. Guo, Z.K.; Gai, C.J.; Cai, C.H.; Chen, L.L.; Liu, S.B.; Zeng, Y.B.; Yuan, J.Z.; Mei, W.L.; Dai, H.F. Metabolites with insecticidal activity from Aspergillus fumigatus JRJ111048 isolated from mangrove plant Acrostichum specioum endemic to hainan island. Mar. Drugs 2017, 15, 381. [CrossRef] [PubMed]

18. Zhang, W.F.; Crickmore, N.; George, Z.; Xie, L.; He, Y.Q.; Li, Y.Z.; Tang, J.L.; Tian, L.; Wang, X.; Fang, X.J. Characterization of new highly mosquitocidal isolate of Bacillus thuringiensis-an alternative to Bti? J. Invertebr. Pathol. 2012, 109, 217-222. [CrossRef] [PubMed] 